\title{
DETECTION AND CHARACTERIZATION OF BACTERIOCIN-PRODUCING LACTOCOCCUS LACTIS STRAINS
}

\author{
Izildinha Moreno $^{1 *}$; Alda L.S. Lerayer'; Mauro F. de Freitas Leitão ${ }^{2}$ \\ ${ }^{1}$ Centro de Tecnologia de Laticínios, Instituto de Tecnologia de Alimentos-ITAL, Campinas, SP, Brazil. \\ ${ }^{2}$ Faculdade de Engenharia de Alimentos-FEA, Universidade Estadual de Campinas-UNICAMP, \\ Campinas, SP, Brazil
}

Submitted: March 22, 1999; Returned to authors for corrections: May 21, 1999. Approved: June 23, 1999

\begin{abstract}
One hundred sixty seven strains of Lactococcus lactis were screened for bacteriocin production by well diffusion assay of GM17 agar. Fourteen $(8.4 \%)$ produced antimicrobial activity other than organic acids, bacteriophages or hydrogen peroxide. The frequency of bacteriocin production ranged from $2 \%$ in L. lactis subsp. cremoris up to $12 \%$ in L. lactis subsp. lactis. Antimicrobial activities were not observed in any strain of L. lactis subsp. lactis var. diacetylactis. Among thirteen bacteriocin-producing strains and two nisin-producing strains (L. lactis subsp. lactis ATCC 11454 and $L$. lactis subsp. lactis CNRZ 150), eight (53\%) were characterized as lactose-positive $\left(\mathrm{Lac}^{+}\right)$and proteinase-negative (Prt). The bacteriocin-producing cultures were also characterized on the basis of plasmid content. All strains had 2 to 7 plasmids with molecular weights varying from 0.5 to 28.1 Mdal. Four strains (ITAL 435, ITAL 436, ITAL 437 and ITAL 438) showed identical profiles and the other were quite distinct.
\end{abstract}

Key words: L. lactis, bacteriocins, fermentation, plasmids

\section{INTRODUCTION}

L. lactis has been traditionally used as starter in the manufacture of cheese and fermented milk products on account of their function of preservation and contribution to flavor and aroma. Selected strains are used as combined cultures, single or as mixture of single cultures. Preservation of fermented foods is due primarily to the conversion of sugars in organic acids with a concomitant lowering of the $\mathrm{pH}$ and removal of large amounts of carbohydrates as nutrient sources. These effects extend the shelf life and safety of the final product $(3,7,26)$.
In recent decades, it has become clear that the overall inhibitory action is due to more complex antagonistic systems produced by the starter cultures. Those systems included the production of the hydrogen peroxide, diacetyl, secondary reaction products, and bacteriocins (3). Competition for essential nutrients, the accumulation of Daminoacids, a lowering of oxidation-reduction potential and coaggregation may also be involved in antagonism (26).

Bacteriocins produced by lactic acid bacteria can be defined as biologically active proteins or protein complexes displaying a bactericidal mode of action

\footnotetext{
* Corresponding author. Mailing address: Instituto de Tecnologia de Alimentos-ITAL, Av. Brasil, 2880. CEP 13.073-001, Caixa Postal 139, Campinas, SP, Brasil. Fax (+5519) 241-5222 Ramal 214. Email: imoreno@ital.org.br
} 
exclusively towards Gram-positive bacteria and particularly closely related species. They form a heterogeneous group with respect to producing bacterial species, molecular size, antibacterial spectrum, mode of action, stability and physical and chemical properties $(6,7)$.

Bacteriocin production was detected in all genera of lactic acid bacteria and have been well described for the subspecies of L. lactis. Kozak et al. (15) observed $88 \%$ of bacteriocin-producing among 67 nisin-non-producing $L$. lactis subsp. lactis strains. In a study with 150 L. lactis subsp. cremoris, Davey and Richardson (5) found 11 (7\%) of strains diplococcinproducing. Geis et al. (9) showed the production of bacteriocin in 65 (23.2\%) of all 280 strains examined. The frequency was of $1 \%$ in L. lactis subsp. lactis var. diacetylactis and $9 \%$ and $7.5 \%$ in L. lactis subsp. lactis and L. lactis subsp. cremoris, respectively. Out of 600 strains isolates from raw buffalo milk by Gupta and Batish (11), 34 (5.7\%) inhibited at least one or more indicator strains. The frequency of production ranged from $3.8 \%$ in L. lactis subsp. cremoris to $6.8 \%$ and $7.6 \%$ in L. lactis subsp. lactis var. diacetylactis and L. lactis subsp. lactis, respectively. Piard et al. (24) found $18 \%$ of L. lactis bacteriocin-producing of all 50 strains examined. Vanderberg et al. (32) reported the production of nisin-like for $8(14.5 \%)$ of all 55 strains examined. Villani et al. (33) founded activity bacteriocin-like in $12(16.7 \%)$ of $L$. lactis subsp. lactis in a total of 72 strains.

With the emergence of psychrotrophic foodborne microorganisms, the development of new food technologies and the search of consumers for natural food products, the bacteriocins and/or producing microorganisms have been recognized as a potential source of biopreservatives for foods. The objective of this study was to evaluate the production of bacteriocins among 167 strains of $L$. lactis belonging to the Lactic Acid Bacteria Collection of the Instituto de Tecnologia de Alimentos, Campinas, SP, Brazil. Bacteriocin-producing strains were evaluated for fermentation characteristics and plasmid profiles.

\section{MATERIALS AND METHODS}

\section{Microorganisms and culture media}

The strains of L. lactis coming from different sources and tested for antagonistic activity are listed in Table 1. The stock cultures were maintained in frozen storage at $-20^{\circ} \mathrm{C}$ in $14 \%$ solids and sterile reconstituted nonfat skim milk powder. Prior to use, the cultures were transferred twice in M17 broth (Oxoid) supplemented with $0.5 \%$ glucose (GM17) and incubated at $30^{\circ} \mathrm{C}$ for $16-18 \mathrm{~h}$. L. lactis subsp. cremoris ITAL 23, ITAL 257 and ITAL 309 were used as indicator cultures. These cultures were previously selected as the most sensitive representatives in the collection (23). The nisin-producing L. lactis subsp. lactis ATCC 11454 and L. lactis subsp. lactis CNRZ 150 were used as positive controls.

Table 1. Origin of lactic acid bacteria strains.

\begin{tabular}{cll}
\hline $\begin{array}{l}\text { Number } \\
\text { of strains }\end{array}$ & \multicolumn{1}{c}{ Species } & \multicolumn{1}{c}{ Origin } \\
\hline 1 & L. lactis subsp. lactis 11454 & ATCC \\
1 & L. lactis subsp. lactis 150 & CNRZ \\
38 & L. lactis subsp. lactis & Raw buffalo milk \\
10 & L. lactis subsp. lactis & Cheese whey \\
10 & L. lactis subsp. lactis & Commercial cultures \\
12 & L. lactis subsp. lactis & Cheese starters cultures \\
30 & L. lactis subsp. lactis & Regional cheese \\
8 & L. lactis subsp. lactis & INRA \\
2 & L. lactis subsp. cremoris & Raw milk \\
8 & L. lactis subsp. cremoris & Commercial cultures \\
1 & L. lactis subsp. cremoris & INRA \\
38 & L. lactis subsp. cremoris & Cheese starter cultures \\
10 & L. lactis subsp. lactis & Commercial cultures \\
& var. diacetylactis & \\
\hline
\end{tabular}

ATCC: American Type Culture Collection, Baltimore, MD, USA; CNRZ and INRA: Centre de Recherches Agronomiques de Jouyen-Josas, France.

\section{Detection of antagonistic activity}

The well diffusion direct assay described by Tagg and McGiven (29) and modified by Benkerroum et al. (2) was utilized to detect the bacteriocinproducing strains. The GM17 broth was supplemented with sodium $\beta$-glycerophosphate ( $2 \%)$ and catalase (Sigma Chemical Co., Dorset, England) at final concentration of $100 \mathrm{U}$. Twenty mililitres of GM17 agar inoculated with $1 \%\left(10^{5}-10^{6} \mathrm{cfu} \mathrm{ml}^{-1}\right)$ of stationary-phase sensitive indicator cultures were poured in a sterile Petri dish and allowed to harden. Holes were punched out of the agar, by using a cork bore ( $4 \mathrm{~mm}$ of diameter). The base of each hole was sealed with a drop $(50 \mu 1)$ of GM17 soft agar $(0.75 \%$ agar) and then filled with $50 \mu 1$ overnight test strains. The inoculated plates were incubated at $30^{\circ} \mathrm{C}$ for 18 $24 \mathrm{~h}$ and checked for the presence of inhibition zones as a result of antimicrobial activity. In addition, two other techniques for inoculation were tested. The test 
producer cultures were inoculated as a single streak and as a spot onto the surface of GM17 agar, previously inoculated with the sensitive indicator cultures. The plates were incubated at $30^{\circ} \mathrm{C}$ for 18 $24 \mathrm{~h}$ and were checked for inhibition zones around the spot and/or the streak.

\section{Detection of lisogenic strains}

To detect the presence of lisogenic strains the reverse side technique was used. GM17 agar plates were streaked with test producer cultures and incubated at $30^{\circ} \mathrm{C}$ for $24 \mathrm{~h}$. The agar was detached from edges of the Petri dish with a sterile spatula and flipped on the lid. The back surface was flooded with $4.5 \mathrm{ml}$ of GM17 soft agar $(0.75 \%$ agar $)$ containing $500 \mu \mathrm{l}$ of a $1: 10 \mathrm{v} / \mathrm{v}$ dilution of the stationary-phase indicator cultures (L. lactis subsp. cremoris ITAL 23, ITAL 257 and ITAL 309). The plates were incubated at $30^{\circ} \mathrm{C}$ for $24-48 \mathrm{~h}$ and examined for inhibition zones (30).

\section{Fermentation characteristics of bacteriocin- producing strains}

Bacteriocin-producing strains were evaluated for the ability of lactose fermentation and proteinase activity. The strains were inoculated (1\%) in $11 \%$ solids and sterile reconstituted nonfat skim milk powder (RSM 11\%), milk RSM 11\% supplemented with milk protein hydrolysate $(0.25 \%)$, milk RSM $11 \%$ supplemented with glucose (1\%) and milk RSM $11 \%$ supplemented with both. The series were incubated at $21^{\circ} \mathrm{C}$ for $16-48 \mathrm{~h}$ and examined for the presence of coagulation and $\mathrm{pH}(21,25)$.

\section{Plasmid profiles of the bacteriocin-producing strains}

Plasmid profile was obtained in order to observe homology between the bacteriocin-producing strains. Cells were grown in GM17 broth at $30^{\circ} \mathrm{C}$ for $6 \mathrm{~h}$. Plasmid extraction and agarose gel electrophoresis followed the method of Anderson and McKay (1) and Maniatis et al. (19). Plasmid profile of L. lactis subsp. lactis ATCC 11454, previously reported (10), was used as a standard.

\section{RESULTS AND DISCUSSION}

\section{Screening for antibacterial activity}

The assays for the presence of bacteriocins were designed to minimize the effect of other interfering inhibitors. For example, to exclude the possibility of an antagonistic effect on indicator strain due to hydrogen peroxide, catalase was added to GM17 agar $(4,11,24,30)$. Likewise, to exclude the inhibition by low $\mathrm{pH}$ due to the production of organic acids, the solid media was supplemented with sodium $\beta$ glicerophosphate $(5,14,27,30)$. Among 167 strains of $L$. lactis screened for antibacterial activity against three indicator strains (L. lactis subsp. cremoris ITAL 23, ITAL 257 e ITAL 309), fourteen (8.4\%) inhibited the growth of all indicator cultures. The average of the inhibition zone diameters for each strain tested is shown in Table 2.

Table 2. Inhibitory activity of 14 strains of $L$. lactis against selected indicator strains

\begin{tabular}{lccc}
\hline \multicolumn{1}{c}{ Microorganisms } & \multicolumn{3}{c}{ Indicator cultures } \\
\cline { 2 - 4 } & ITAL 23 & ITAL 257 & ITAL 309 \\
\hline L. lactis subsp. cremoris ITAL 402 & ++ & ++ & + \\
L. lactis subsp. lactis ITAL 104 & +++ & ++ & ++ \\
L. lactis subsp. lactis ITAL 179 & +++ & +++ & ++ \\
L. lactis subsp. lactis ITAL 185 & +++ & ++ & ++ \\
L. lactis subsp. lactis ITAL 187 & +++ & +++ & + \\
L. lactis subsp. lactis ITAL 383 & ++ & ++ & + \\
L. lactis subsp. lactis ITAL 387 & +++ & ++ & ++ \\
L. lactis subsp. lactis ITAL 403 & +++ & ++ & ++ \\
L. lactis subsp. lactis ITAL 404 & +++ & ++ & + \\
L. lactis subsp. lactis ITAL 408 & ++ & ++ & + \\
L. lactis subsp. lactis ITAL 435 & +++ & +++ & ++ \\
L. lactis subsp. lactis ITAL 436 & +++ & +++ & ++ \\
L. lactis subsp. lactis ITAL 437 & +++ & +++ & ++ \\
L. lactis subsp. lactis ITAL 438 & +++ & +++ & ++ \\
\hline
\end{tabular}

+: Weak inhibition (zone of $4 \mathrm{~mm}$ of diameter); ++ Moderate inhibition (zone of 5-9mm); +++: High inhibition (zone of 10$15 \mathrm{~mm})$

The comparison among the methods of simultaneous antagonism assay (inoculation in spot, streak and wells) showed that the inoculation in wells lead to the formation of larger and more consistent inhibition zones. Indeed, these methods allowed the standardization of the inoculum, making possible the comparison between diameters of the inhibition zones (29). Benkerroum et al. (2) had concluded that this method is suitable and designated "lyse zones" as opposed to the spot-onthe-law method. The lyse zones could be seen after $3 \mathrm{~h}$ of incubation by wells diffusion method, while $48 \mathrm{~h}$ were necessary to see definitive inhibition zones by the spot test assay or streak inoculation. However, Lewis et al (17) reported that the spot 
method was more reproducible, rapid and easy to score than flip-plate or well diffusion methods. Spelhaug and Harlander (27) also found the spot method superior to flip-plate method assay in a study of three bacteriocin-producing strains against a large panel of food-borne microorganisms. The antagonism deferred method for inoculation in points was more suitable when compared with the streak and wells methods due to its reproducibility, rapidity and simplicity (17).

\section{Detection of lisogenic strains}

Lisogenic strains and bacteriocin-producing strains show similar spots. The differentiation between them is difficult, which interferes with the result evaluation $(20,30,34)$. An important differential characteristic is that bacteriocins, unlike bacteriophages, do not carry the genetic determinants necessary for self-replication within susceptible organisms. Only the bacteriophages can propagate in sensitive strains $(20,22,30)$.

Based on the capacity of bacteriocins to diffuse in agar, the reverse technique, which eliminated the contact between the producers and sensitive strains, was used for lyse differentiation (30). The formation of the diffusion zones was observed after incubation of the Petri dishes, previously streaked with the producer strains and subsequent addition of the soft agar seeded with the sensitive strains, in the reverse side. This indicated that the substance diffuses into the agar (30). Alternatively, the observation of the characteristics of the inhibition zones helped in the differentiation of the nature of the inhibitory substance. Increasing the dilution factor resulted in reduction of the diameter of the inhibition zones until its total disappearance, indicating the presence of bacteriocins. In high dilutions the formation of the lysis plaque, characteristic of the presence of bacteriophages or bacteriocin activity, was not observed, whereas if present, phages would still be detected at much higher dilution $(16,20)$.

Of the 167 strains tested, $14(8.4 \%)$ showed bacteriocin activity against all to the indicator cultures (Table 3 ). Thirteen $(92.9 \%)$ strains are L. lactis subsp. lactis and only one (7.1\%) strain is L. lactis subsp. cremoris. The frequency of bacteriocin production ranged from $2 \%$ in L. lactis subsp. cremoris to $12 \%$ in L. lactis. None of the $L$. lactis subsp. lactis biovar. diacetylactis strains tested in the study was able to produce bacteriocins.
Table 3. Occurrence of bacteriocin-producing L. lactis.

\begin{tabular}{lccc}
\hline \multirow{2}{*}{ Species } & \multicolumn{2}{c}{ Number of strains } & $\%$ \\
\cline { 2 - 3 } & Tested* & Sensitive & \\
\hline L. lactis subsp. cremoris & 49 & 1 & 2 \\
L. lactis subsp. lactis & 108 & 13 & 12 \\
$\begin{array}{l}\text { L. lactis subsp. lactis } \\
\text { var. diacetylactis }\end{array}$ & 10 & 0 & 0 \\
\hline \multicolumn{1}{c}{ Total } & 167 & 14 & 8.4 \\
\hline
\end{tabular}

* By the well-diffusion assay

The screening for the detection of bacteriocinproducing strains is highly dependent on several factors: testing method, composition of the culture medium and nature of the indicator culture. The choice of the indicator (bacteriocin-sensitive strain) used in the screening is very important and may greatly influence the results (22). Therefore, the confrontation of the results achieved with those of others authors is very difficult. Nevertheless, the occurrence of bacteriocin-producing lactococci in this study is similar to that found in the literature: 8\% Vandenberg et al. (32), 5.7\% Gupta and Batish (11) and 7.3\% Davey and Richardson (5). In counterpart, these results are higher than those obtained by Zezza et al. (35) $1.5 \%$ or Uhlman et al. (31) $1.6 \%$ and lower than those from Villanni et al. (33) $16.7 \%$, Piard et al. (24) $18 \%$, Geis et al. (9) $25 \%$ and Kozak et al. (15) $88 \%$.

Table 4 shows the origin of the bacteriocinproducing strains of $L$. lactis selected in this study. Among 13 L. lactis subsp. lactis strains, 6 (46.1\%) were isolated from raw milk, 3 (23.1\%) from regional cheese and $4(30.8 \%)$ from industrial lactic starters. L. lactis subsp. cremoris was isolated from industrial lactic starters.

Table 4. Origin of L. lactis bacteriocin-producing strains.

\begin{tabular}{lcc}
\hline \multirow{2}{*}{ Origin } & \multicolumn{2}{c}{ Species (\%) } \\
\cline { 2 - 3 } & $\begin{array}{c}\text { L. lactis } \\
\text { subsp. cremoris }\end{array}$ & $\begin{array}{c}\text { L. lactis } \\
\text { subsp. lactis }\end{array}$ \\
\hline Raw milk & 0.0 & 46.1 \\
Regional cheese & 0.0 & 23.1 \\
Cheese starter cultures & 2.0 & 30.8 \\
\hline
\end{tabular}

\section{Fermentation characteristics of bacteriocin- producing strains}

The fermentation characteristics of bacteriocinproducing strains were evaluated after $24 \mathrm{~h}$ at $21^{\circ} \mathrm{C}$ in $11 \% \mathrm{RSM}$ milk and the same medium 
supplemented with $1.0 \%$ glucose, $0.25 \%$ milk protein hydrolysate or both. The nisin-producing strains $L$. lactis subsp. lactis ATCC 11454 and L. lactis subsp. lactis CNRZ 150 were also included in this test. Seven cultures were classified as fast strains (ITAL 104, ITAL 179, ITAL 187, ITAL 403, ITAL 404, ITAL 408 and CNRZ 150). They coagulated milk within $16 \mathrm{~h}$ at $21^{\circ} \mathrm{C}$. Eight strains required $16 \mathrm{~h}$ or more to coagulate milk, and were classified as slow (ITAL 185, ITAL 383, ITAL 387, ITAL 435, ITAL 436, ITAL 437, ITAL 438 and ATCC 11454). Slow variants may be defective in lactose metabolism ( $\mathrm{Lac}^{-}$) and/or proteinase activity $\left(\mathrm{Prt}^{+}\right)$. These characteristics are carried on plasmids in some strain (13).

In glucose-supplemented milk, the slow cultures remained defective in proteolytic enzyme activity but did lower the $\mathrm{pH}$, indicating that glucose was being fermented. When the milk was supplied with an exogenous nitrogen source, the cultures showed slow fermentation of glucose as evidenced by the decrease in $\mathrm{pH}$. To determine the characteristic $\mathrm{Prt}^{-}$, the cultures were grown in milk supplemented with glucose or glucose plus an exogenous nitrogen source. The cultures were Prt $^{-}$since that had little, if any, proteolytic activity. This was confirmed by low $\mathrm{pH}$ that did occur if the glucose was supplemented with a nitrogen source. This indicated that the inability to produce acid from glucose was due to the inability to acquire needed nitrogenous compounds $(12,21,25)$.

Eight (53\%) out of 15 strains were characterized as lactose-positive and proteinase-negative ( $\mathrm{Lac}^{+} \mathrm{Prt}$ )
(Table 5). Vandenberg et al. (32) showed that 21.6\% of lactic acid bacteria isolated from different sources lacked any sign of extracellular proteolytic activity. This confirmed the inability of bacteriocin-producing lactococci to grow and to produce acid at rates suitable for cheese manufacture. The failure acid production by lactococci when grown in milk is due to the lack of the proteinase enzyme system $(8,18$, $25)$. Strains lacking this enzyme system are designated as proteinase-negative, and they grow in milk only until soluble nitrogenous compounds are depleted (25). The reasons for the lack of proteinase activity among nisin-producing lactococci are the loss of the proteinase and incompatibility of the genes for proteinase activity with the genetic elements encoding bacteriocin production $(25,28)$.

\section{Plasmid profiles of the lactococci bacteriocin- producing}

Table 6 shows the molecular weight of the plasmids found in bacteriocin-producing strains selected in this study. The L. lactis subsp. lactis ATCC 1454 contain six plasmids with molecular weights of 31.8, 29.1, 21.9, 19.4, 3.6 and 1.49 Mdal (10). Agarose gel eletrophoresis of isolated DNA samples revealed two to seven plasmids in these cultures. Their molecular weights ranged from 0.5 to 28.1 Mdal when compared with standard plasmids (Table 6). No plasmids larger than 100 Mdal were observed. The strains L. lactis subsp. lactis ITAL 435, ITAL 436, ITAL 437 and ITAL 438 showed similar plasmid profiles. These cultures were isolated

Table 5. Number and molecular weight of plasmids found in bacteriocin-producing L. lactis subsp. lactis strains.

\begin{tabular}{|c|c|c|}
\hline \multirow[t]{2}{*}{ Bacteriocin-producing strains } & \multirow[b]{2}{*}{ Number } & \multirow{2}{*}{$\begin{array}{c}\text { Plasmids } \\
\text { Molecular weight (Mdal) }\end{array}$} \\
\hline & & \\
\hline L. lactis subsp. lactis ITAL 104 & 5 & $26.4 ; 25.9 ; 14.2 ; 9.4 ; 0.7$ \\
\hline L. lactis subsp. lactis ITAL 179 & 4 & $26.8 ; 25.9 ; 9.8 ; 0.5$ \\
\hline L. lactis subsp. lactis ITAL 185 & 5 & $26.4 ; 23.7 ; 14.6 ; 8.9 ; 3.8$ \\
\hline L. lactis subsp. lactis ITAL 187 & 4 & $25.5 ; 24.6 ; 23.7 ; 9.8$ \\
\hline L. lactis subsp. lactis ITAL 383 & 2 & $27.7 ; 25.9$ \\
\hline L. lactis subsp. lactis ITAL 387 & 5 & $28.1 ; 26.8 ; 23.7 ; 13.8 ; 2.9$ \\
\hline L. lactis subsp. lactis ITAL 403 & 7 & $27.7 ; 26.8 ; 25.5 ; 23.7 ; 20.7 ; 9.4 ; 1.2$ \\
\hline L. lactis subsp. lactis ITAL 404 & 4 & $26.8 ; 25.9 ; 9.4 ; 1.2$ \\
\hline L. lactis subsp. lactis ITAL 408 & 4 & $28.1 ; 27.2 ; 13.8 ; 5.1$ \\
\hline L. lactis subsp. lactis ITAL 435 & 4 & $28.1 ; 26.8 ; 23.7 ; 22.4$ \\
\hline L. lactis subsp. lactis ITAL 436 & 4 & $28.1 ; 26.8 ; 23.7 ; 22.4$ \\
\hline L. lactis subsp. lactis ITAL 437 & 4 & $28.1 ; 26.8 ; 23.7 ; 22.4$ \\
\hline L. lactis subsp. lactis ITAL 438 & 4 & $28.1 ; 26.8 ; 23.7 ; 22.4$ \\
\hline
\end{tabular}


from raw milk and may be derived from the same strain.

Table 6. Fermentation characteristics of bacteriocin-producing lactococci at $21^{\circ} \mathrm{C}$ for $24 \mathrm{~h}$ in $11 \% \mathrm{RSM}$, supplemented or not with $1.0 \%$ glucose, $0.25 \%$ milk protein hydrolysate or both.

\begin{tabular}{|c|c|}
\hline Bacteriocin-producing strains & $\begin{array}{l}\text { Fermentation } \\
\text { characteristics* }\end{array}$ \\
\hline L. lactis subsp. lactis ITAL 104 & $\mathrm{Lac}^{+} \operatorname{Prt}^{+}$ \\
\hline L. lactis subsp. lactis ITAL 179 & $\mathrm{Lac}^{+} \operatorname{Prt}^{+}$ \\
\hline L. lactis subsp. lactis ITAL 185 & $\mathrm{Lac}^{+} \mathrm{Prt}^{-}$ \\
\hline L. lactis subsp. lactis ITAL 187 & $\mathrm{Lac}^{+} \operatorname{Prt}^{+}$ \\
\hline L. lactis subsp. lactis ITAL 383 & $\mathrm{Lac}^{+} \operatorname{Prt}^{-}$ \\
\hline L. lactis subsp. lactis ITAL 387 & $\mathrm{Lac}^{+} \operatorname{Prt}^{-}$ \\
\hline L. lactis subsp. lactis ITAL 403 & $\mathrm{Lac}^{+} \mathrm{Prt}^{+}$ \\
\hline L. lactis subsp. lactis ITAL 404 & $\mathrm{Lac}^{+} \operatorname{Prt}^{+}$ \\
\hline L. lactis subsp. lactis ITAL 408 & $\mathrm{Lac}^{+} \mathrm{Prt}^{+}$ \\
\hline L. lactis subsp. lactis ITAL 435 & $\mathrm{Lac}^{+} \operatorname{Prt}^{-}$ \\
\hline L. lactis subsp. lactis ITAL 436 & $\mathrm{Lac}^{+} \operatorname{Prt}^{-}$ \\
\hline L. lactis subsp. lactis ITAL 437 & $\mathrm{Lac}^{+} \mathrm{Prt}^{-}$ \\
\hline L. lactis subsp. lactis ITAL 438 & $\mathrm{Lac}^{+} \operatorname{Prt}^{-}$ \\
\hline L. lactis subsp. lactis CNRZ 150 & $\mathrm{Lac}^{+} \operatorname{Prt}^{+}$ \\
\hline L. lactis subsp. lactis ATCC 11454 & $\mathrm{Lac}^{+} \mathrm{Prt}^{-}$ \\
\hline
\end{tabular}

* Lac + Prt: Lactose-positive and proteinase-negative

** $\mathrm{Lac}^{+} \mathrm{Prt}^{+}$: Lactose-positive and proteinase-positive

On the basis of plasmid profiles the bacteriocinproducing strains were classified in three categories according to Gupta and Batish (11). Group I (low plasmid group) comprised one strain (ITAL 383), with one to three plasmids. Group II (moderate plasmid group) comprised eight strains (ITAL 104, ITAL 179, ITAL 185; ITAL 187, ITAL 387, ITAL 404, ITAL 408; ITAL 435, ITAL 436, ITAL 437 and ITAL 438), with four to five plasmids. Group III (high plasmid group) comprised one strain (ITAL 403), with six or more plasmids.

Our results showed that antagonistic substances produced by the tested strains are bacteriocins and suggest that bacteriocin-producing lactococci are present in low number in the environment These substances were heat resistant and their proteinaceous nature was demonstrated by sensibility to proteolytic enzyms (23). They also demonstrate the inability of bacteriocin-producing lactococci to grow and to produce acid at rates suitable for cheese manufacture. Due to these factors, the use of bacteriocin-producing starter have not been fully successful in dairy products

\section{ACKNOWLEDGEMENTS}

Izildinha Moreno would like to thank to the Conselho Nacional de Desenvolvimento Científico e Tecnológico-CNPq for the concession of a scholarship for probation in the Institut National de Recherches Agronomiques-INRA, Jouy-en-Josas, France and to her supervision by Dr. Jean Richard and Dr. Michel Desmazeaud.

\section{RESUMO}

\section{Detecção e caracterização de Lactococcus lactis produtores de bacteriocinas}

Um total de 167 linhagens de L. lactis foi selecionado para os testes de produção de bacteriocinas pelo método de difusão em poços em agar GM17. Desse total, 14 (8.4\%) produziram substâncias inibidoras que não foram associadas com ácidos orgânicos, peróxido de hidrogênio e bacteriófagos. A frequência de produção de bacteriocinas variou de $2 \%$ em L. lactis subsp. cremoris a $12 \%$ em L. lactis subsp. lactis. Nenhuma das linhagens de L. lactis subsp. lactis var. diacetylactis produziu substâncias inibidoras. De 13 linhagens produtoras de bacteriocinas e duas de nisina (L. lactis subsp. lactis ATCC 11454 e L. lactis subsp. lactis CNRZ 150), 8 (53\%) foram caracterizadas como lactose-positivas $\left(\mathrm{Lac}^{+}\right)$e proteinase-negativas $\left(\mathrm{Prt}^{-}\right)$. As linhagens produtoras de bacteriocinas também foram caracterizadas no seu conteúdo de plasmídios. Elas apresentaram de 2 a 7 plasmídios, com pesos moleculares aproximados de 0.5 a 28.1 Mdal. Quatro linhagens (ITAL 435, ITAL 436, ITAL 437 e ITAL 438) mostraram idênticos perfis de plasmídios. Os perfis das linhagens restantes foram distintos.

Palavras-chave: L. lactis, bacteriocinas, fermentação, plasmídios

\section{REFERENCES}

1. Anderson, D.G. and McKay, L.L. Simple and rapid method for isolating large plasmid DNA from lactic streptococci. Appl. Microbiol. 46: 549-552, 1983.

2. Benkerroum, N.; Ghouati, Y.; Sandine, W.E.; TantaquiElaraki, A. Methods to demonstrate the bactericidal activity of bacteriocins. Lett. in Appl. Microbiol. 17: 78-81, 1993. 
3. Daeschel, M. A. Antimicrobial substances from lactic acid bacteria for use as food preservative. Food Technol., 43: 164167, 1989.

4. Davey, G.P. Mode of action of diplococcin, a bacteriocin from Streptococcus cremoris 346. N. Z. J. Dairy Sci. Technol., 16:187-190, 1981

5. Davey, G.P. and Richardson, B.C. Purification and some properties of diplococcin from Streptococcus cremoris 346. Appl. Environ. Microbiol., 41:84-89, 1981.

6. Davidson, P.M. and Hoover, D.G. Antimicrobial components from lactic acid bacteria. In: Salminen, S. and von Wright, A. (eds). Lactic Acid Bacteria. Marcel-Dekker, New York, 1993, p. 127-150.

7. De Vuyst, L. and Vandamme, E.J. Lactic acid bacteria and bacteriocins: their practical importance. In: De Vuyst, 1. \& Vandamme, E.J. (eds). Bacteriocins of Lactic Acid Bacteria. Microbiology, Genetics and Application. Chapman \& Hall, New York, 1994, p. 1-12.

8. Exterkate, F.A. The proteolytic systems of a slow lactic-acidbacteria producing variant of Streptococcus cremoris. Neth. Milk Dairy J., 30: 3-8, 1976.

9. Geis, A.; Singh, J.; Teuber, M. Potential of lactic streptococci to produce bacteriocin. Appl. Environ. Microbiol. 45: 205211,1983

10. Gonzales, C.F. and Kunka, B.S. Transfer of sucrosefermenting ability and nisin production phenotype among lactic streptococci. Appl. Environ. Microbiol., 49: 627-633, 1985.

11. Gupta, R. K. and Batish, V. K. Screening of lactic streptococci for antibacterial activity, plasmid profils and biochemical performance. MAN, 8:45-52, 1990.

12. Heap, H.A. and Richardson, G.H. The proteolytic effect of fast-coagulating and slow-coagulating strain of Streptococcus cremoris. N. Z. J. Dairy Sci. Technol., 20: 155-161, 1985.

13. Huggins, A.R. and Sandine, W.E. Differentation of fast and slow milk-coagulating isolates in strains of lactic streptococci. J. Dairy Sci., 67: 1674-1679, 1984.

14. Kojic, M.; Svircevic, J.; Banina, A.L.; Topisirovic, L. Bacteriocin producing strain of Lactococcus lactis subsp. diacetylactis S50. Appl. Environ. Microbiol., 57: 1835-1837, 1991.

15. Kozak, W.; Bardowski, J.; Dobrzanski, W.T. Lactostrepcinsacid bacteriocins produced by lactic streptococci. J. Dairy Res., 45: 247-257, 1978.

16. Larsen, A.G.; Vogensen, F.K.; Josephsen, J. Antimicrobial activity of lactic acid bacteria isolated from sour doughs: purification and characterization of bavaricin $\mathrm{A}$, a bacteriocin produced by Lactobacillus bavaricus MI401. J. Appl. Bacteriol., 75: 113-122, 1993.

17. Lewis, C.B.; Kaiser, A.; Montville, T.J. Inhibition of foodborne bacterial pathogens by bacteriocins from lactic acid bacteria isolated from meat. Appl. Environ. Microbiol., 57: 1683-1688, 1991.

18. Lipinska, E. Use of nisin producing lactic streptococci in cheese making. FIL-IDF Annual Bulletim, Brussels, 73: 137, 1973.

19. Maniatis, T.; Fritsch, E.F.; Sambrookk, J. Molecular Cloning: a Laboratory Manual. Cold Spring Harbor Laboratory. New York, 1982.
20. Mayr-Harting, A.; Hedges, A.J.; Berkeley, C.W. Methods for studying bacteriocins. In: Norris, J. R. and Ribbons, D. W. (eds). Methods in Microbiology. Academic Press Inc., New York, 1972, p.316-422.

21. MacKay, L.L. and Baldwin, K.A. Simultaneous loss of proteinase and lactose utilizing enzyme activities in Streptococcus lactis and reversal of loss by tranduction. Appl. Microbiol. 28: 342-346, 1974.

22. Montville, T. J. and Kaiser, A. Antimicrobial proteins: classification, nomenclature, diversity, and relationship to bacteriocins. In: Hoover D.G. and Steenson L.R. (eds). Bacteriocins of Lactic Acid Bacteria. Academic Press, New York, 1993, p.1-22.

23. Moreno, I. Ocorrência e caracterização de bacteriocinas de lactococos e sua utilização no processamento de queijo Minas Frescal. São Paulo, 1995, 203p. (Tese de Mestrado. Faculdade de Ciências Farmacêuticas. USP).

24. Piard, J.C.; Delorme, F.; Giraffa, G.; Commissaire, J. and Desmazeaud, M. Evidence for a bacteriocin produced by Lactococcus lactis CNRZ 481. Neth. Milk Dairy J., 44: $143-$ $158,1990$.

25. Roberts, R.F.; Zottola, E. A.; McKay, L.L. Use of a nisinproducing starter culture suitable for cheddar cheese manufacture. J. Dairy Sci., 75: 2353-2363, 1992.

26. Schillinger, U. Bacteriocins of lactic acid bacteria. In: Bills, D.D. and Kung, S. (eds). Biotechnology and Food Safety. Butterworth-Heinemann, Boston, 1990. p. 55-74.

27. Spelhaug, S.R. and Harlander, S.K. Inhibition of foodborne bacterial pathogens by bacteriocins from Lactococcus lactis and Pediococcus pentosaceus. J. Food Prot., 52: 856-862, 1989.

28. Steele, J. L. and McKay, L. L. Partial characterization of the genetic basis for sucrose metabolism and nisin production in Streptococcus lactis. Appl. Environ. Microbiol. 58: 1786$1788,1986$.

29. Tagg, J.R. and McGiven, A.R. Assay System for bacteriocins. Appl. Microbiol., 21: 943, 1971.

30. Tagg, J. R.; Dajani A. S.; Wannamaker L.W. Bacteriocins of gram-positive bacteria. Bacteriol. Rev., 40: 722-756, 1976.

31. Uhlman, L.; Schillinger, U.; Rupnow, J.R. and Holzapfel, W.H. Identification and characterization of two bacteriocinproducing strains of Lactococcus lactis isolated from vegetables. Int. J. Food Microbiol., 16: 141-151, 1992.

32. Vandenberg, D.J.C.; Smits, A.; Pot, B.; Ledeboer, A. M.; Kersters, K.; Verbakel, J. M. A.; Verrips, T. Isolation, screening and identification of lactic acid bacteria from traditional food fermentation processes and culture collections. Food Biotechnol., 7: 189-205, 1993.

33. Villanni, F.; Pepeo, O.; Moschetti, G.; Salzano, G.; Parente, E.; Coppola, S. Antagonistic activity of lactic acid bacteria isolated from natural whey starters for water-buffalo mozzarella cheese manufacturing. Italian J. Food Sci. 3: 221$235,1995$.

34. Zacconi, C. Bactteriocine e antibiotici prodotti dai batteri lattici. In: Bottazzi, V., (ed) Aggiornamento di microbiologia dei batteri lattici. Piacenza, 1987. p. 57-92.

35. Zezza, N.; Pasini, G.; Lombardi, A.; Mercenier, A.; Spettoli, P.; Zamorani, A.; Nutti, P. Production of a bacteriocin active on lactate-fermenting clostridia by Lactococcus lactis supbsp. lactis in coated alginate beads. J. Dairy Res., 60:581-591, 1993. 